\title{
Words That Kill: Rhetoric and Reality in the Discourse of the Front National
}

\author{
Palavras que matam: retórica e realidade da frente \\ nacional francesa
}

\author{
Palabras que matan: la retórica y la realidad \\ del frente nacional francés
}

\begin{abstract}
Since Marine Le Pen's accession to the leadership of France's National Front, in 2011, she has concertedly sought to "normalize" the party's far-right political platform and rhetoric. In this respect, she has been wildly successful: party membership has doubled from 40,000 to 80,000 , and its electoral base has greatly expanded. Thus since the May 2014 European parliamentary elections, the National Front has become France's leading vote getter. In the first round of the December 2015 regional elections, it attained an unprecedented $28 \%$ of the vote. Given Europe's ongoing migration crisis as well as the spate of recent terrorist attacks that has shaken confidence in the capacity of France's mainstream parties to keep the nation safe, many analysts have forecast a National Front victory in the upcoming 2017 presidential elections. The successful "normalization" of the National Front under Marine Le Pen's leadership raises the important question: are the differences with the old National Front, as led by Marine's father Jean-Marie Le Pen, disparities of substance or are they largely rhetorical? Attention to the subtleties and nuances of political language yield a results that are both revealing and highly disturbing.
\end{abstract}

Resumo Desde a ascensão de Marine Le Pen à liderança da Frente Nacional Francesa, em 2011, ela concertadamente procurou "normalizar" a plataforma política e a retórica do partido de extrema direita. A esse respeito, foi muito bem-sucedida: a filiação ao partido dobrou de 40 mil para 80 mil, e sua base eleitoral expandiu-se enormemente. Assim, desde as eleições parlamentares europeias de maio de 2014, a Frente Nacional tornou-se a liderança de votos na França. No primeiro turno das eleições regionais de dezembro de 2015 , atingiu $28 \%$ dos votos sem precedentes. Dada a crise europeia em curso da migração tanto quanto a onda de recentes ataques terroristas que abalaram a confiança na capacidade dos principais partidos políticos da França em manter a segurança da nação, muitos analistas previram uma vitória da Frente Nacional nas próximas eleições presidenciais de 2017. A

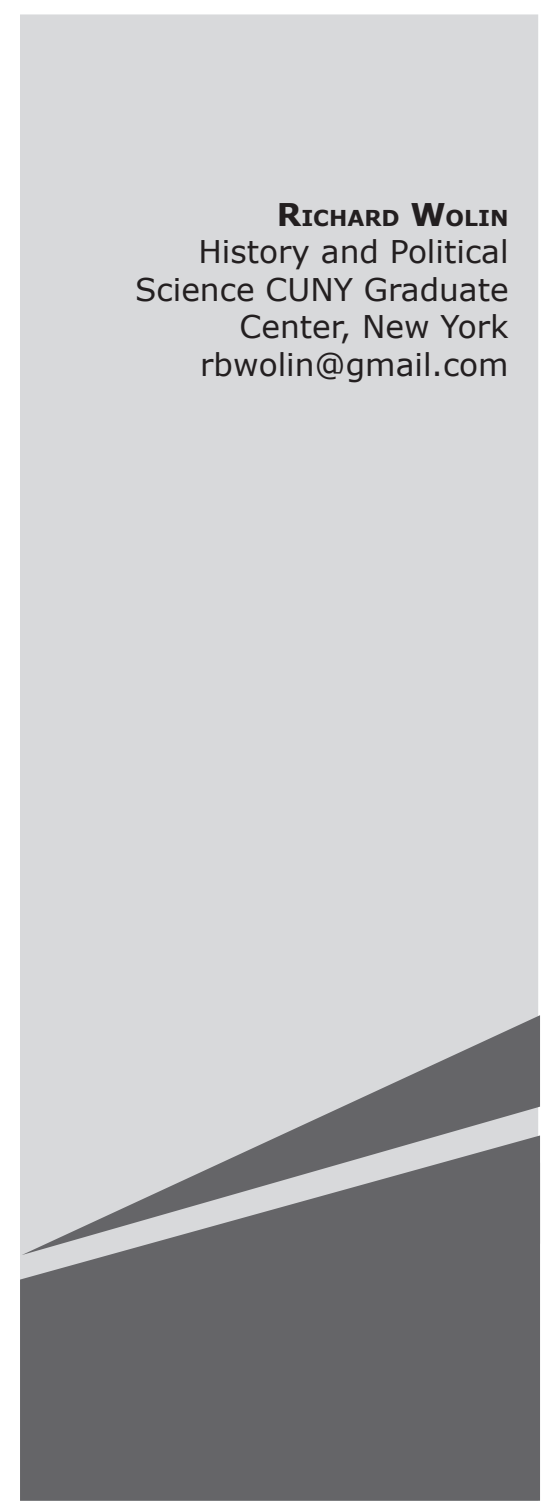


"normalização" bem-sucedida da Frente Nacional sob a liderança de Marine Le Pen levanta a importante questão: as diferenças com a velha Frente Nacional, como conduzida pelo pai de Marine, Jean-Marie Le Pen, são disparidades da substância ou, em grande parte, são retóricas? Atenção às sutilezas e nuanças da linguagem política produz resultados que são tanto reveladores quanto altamente perturbadores.

Resumen Desde que Marine Le Pen assumió la dirección del Front Nacional de Francia en 2011, ella trató de "normalizar" la plataforma política y la retórica del partido de extrema derecha. En este sentido, fue muy exitosa: el número de miembros del partido se duplicó de 40.000 a 80.000 , y su base electoral se ha expandido enormemente. Por lo que, desde las elecciones al Parlamento Europeo en mayo de 2014, el Frente Nacional se assumió el liderazgo de la votación en Francia. En la primera vuelta de las elecciones regionales de diciembre de 2015, alcanzó el 28\% de los votos sin precedentes. Dada la crisis europea de la migración en curso tanto como la ola de ataques terroristas recientes que sacudieron la confianza en la capacidad de los principales partidos políticos de Francia en el mantenimiento de la seguridad de la nación, muchos analistas predijeron una victoria del Front Nacional en las próximas elecciones presidenciales en 2017. Estes resultados que ponen el Front Nacional en la delantera bajo el liderazgo de Marine Le Pen plantea la pregunta importante: las diferencias con el antiguo Front Nacional, como se lleva a cabo por el padre de Marina, Jean-Marie Le Pen son diferencias de fondo o son en gran parte de la retórica? Atención a las sutilezas y matices del lenguaje político produce resultados que son a la vez revelador como muy preocupante.

On May 21, 2013, the hexagon was traumatized by a horrific, headline-grabbing episode. A nattily attired man in his late $70 \mathrm{~s}$ committed suicide by shooting himself with a pistol in front of 1500 worshipers attending Tuesday morning services at the Notre Dame cathedral in central Paris. The man's name was Dominique Venner.

Venner's suicide note bore the rather curious title, "The May 26 Protest and Heidegger". Thereby, he alluded to an uncanny confluence of events: the next "Manif pour Tous" demonstration - the ongoing right-wing protest movement against gay marriage which, since 2013, has upset the French political status quo - had been scheduled to take place on May 26, five days after Venner took his own life. By the same token, May 26, 1976 was the day that the twentieth century's most prominent philosophical advocate of National Socialism, Martin Heidegger, breathed his last breath.

In order to explain his actions, Venner invoked the names of three prominent fellow suicides he viewed as fraternal spirits: two French literati who had been collaborateurs and enthusiasts of fascism in its French iteration, Henry de Montherlant (1895-1972) and Pierre Drieu la Rochelle (1893-1945); and, finally, the Japanese ultra-nationalist writer, Yukio Mishima.

As the foregoing details attest, Venner's act was indisputably meant to be a political gesture. 
In his suicide note, which was read aloud by a friend later in the day on a right-wing radio station, Venner provided the following justification of his shocking deed:

I revolt . . . against individual desires that have destroyed the pillars of [French] identity [ancrages identitaires], notably, the family, the intimate foundation of our age-old [multimillénaire] civilization. Although I defend the identities of all peoples in their native lands, I take umbrage at the crime committed by those who seek to replace our [European] populations.

Here, it is worth noting that Venner's concluding allusion to "population replacement" is a standard New Right/Nouvelle Droite ideological coinage, insinuating that the goal of immigration policy is to supplant ethnic Europeans with alien races that hail from the ghettoes of the developing world. Today, one of the linchpins the febrile far-right worldview is the idea that immigration is part of a "liberal," "cosmopolitan" plot whose goal is to decimate indigenous Europeans.

On first view, the allusion to Heidegger in the title of Venner's note might seem, gratuitous or obscure. However, nine years earlier, Venner had had been one of the co-founders of the "Bloc Identitaire," a European-wide, chauvinistic, anti-immigrant movement. And among the so-called "identitarians," Heidegger, on the basis of his right-wing, völkisch views, is frequently celebrated as a renowned ideological precursor.

A few hours after Venner's carefully choreographed finale at the Notre Dame Cathedral, National Front leader Marine Le Pen - who, according to most opinion polls is the frontrunner in the presidential election scheduled for spring 2017 - sent out the following heartfelt condolence tweet: "We wish to convey our wholehearted respect for Dominique Venner, whose final gesture, an eminently political act, sought to bestir the people of Fran- ce from their slumber." What is astonishing about this statement is that, despite Le Pen's knowledge of Venner's checkered past as an anti-republican, far-right political activist and conspirator, she had no compunction about characterizing his suicide - a blasphemous act that was committed in France's most venerated religious sanctuary - as an inherently praiseworthy deed.

Dominque Venner, who was born in 1935 , is someone who might be described as an inherently dubious figure. For nearly six decades, he was an animating and rather shady presence among neo-Nazi and extreme-right groups that flourished on the margins of French society. During the 1950s, Venner was one of the founders of Jeune Nation: an anti-Republican organization that was comprised of neofascists, anti-Semites, and former Vichyites. .

During the 1950 s and early 1960s, Jeune Nation militants were passionately engaged in the struggle for French Algeria. Prior to founding Jeune Nation, Venner had served as a paratrooper in the sanguinary Algerian war. Following the Battle of Algiers (1957), Jeune Nation acted as the political wing of the OAS (Organisation de l'armée secrète), whose acts of terrorism - including a failed assassination attempt against Charles de Gaulle - brought metropolitan France to the brink of civil war.

In May 1958, a few days after de Gaulle's coup, Jeune Nation was banned for sedition. Three years later, as the OAS attacks reached fever pitch following a failed summons to insurrection, Venner and five other Jeune $\mathrm{Na}$ tion activists were arrested and sentenced to prison for sedition.

Upon emerging from prison in 1963, Venner well nigh single-handedly reconceived the paradigm of postwar European neofascism, redirecting its focus away from past struggles that had already been lost - e.g., the Third Reich, the Vichy regime, and French Al-

1 Cited in Le Monde, May 22, 2013: “Tout notre respect à Dominique Venner dont le dernier geste, éminemment politique, aura été de tenter de réveiller le peuple de France. MLP." 
geria - and toward the future in which the goals of Aryan superiority could be realized on a pan-European scale. As Venner asserted in his 1963 influential pamphlet, Qu'est-ce que c'est que le nationalisme:

Militants of a white nation need to find ideological sustenance beyond their borders: support that explains their struggle, praises their courage... and that awakens the feeling of struggle for survival among white peoples everywhere against those who seek to destroy them ${ }^{2}$ (VENNER QUOTE, Algazy, 172-73).

At around the same time, Venner also founded a "metapolitical" organization, "Europe-Action," that featured a journal of the same name.

Shortly after Europe-Action was established, Venner discovered an ideal protégé: a 22-year-old university student named Alain de Benoist (1942-). In what, in retrospect, seems to be a sinister case of pre-established harmony, de Benoist, as the inheritor and beneficiary of Europe-Action's neofascist worldview, would soon become the mastermind of the Nouvelle Droite. Ultimately, the Nouvelle Droite's strategy of "total ideological saturation" - an orientation that was inspired by Venner's "metapolitical" approach - would come to fruition two decades later with the National Front's political breakthrough in the 1984 elections for the European Parliament.

In retrospect, the ideational seeds of the National Front's [FN] political ascendancy were planted during the 1960 s with the program of neofascist intellectual renewal that was nurtured by Europe-Action and its various successor organizations such as GRECE (Groupement de Recherche et Etudes sur la Culture Européene), which was the brainchild of de Benoist and his associates. In this respect, Venner's "metapolitical” strategy of shunning institutional politics in favor of

Venner, Europe-Action, (May 1963), 5. laying the ideological groundwork for a future seizure of power seems to have paid off handsomely. During the 1980s, a number of prominent New Rightists - Yvan Blot, Bruno Gollnisch, Jean-Yves Le Gallou, and Bruno Mégret - migrated from GRECE and its sister organizations to positions of influence and leadership within National Front. ${ }^{3}$

In assessing the Nouvelle Droite's endemic fear of métissage or "ethnic mixing," it is not hard to discern its manifestly racist subtext or gist: it seeks to pit "Aryans" or "Indo-Europeans" against non-European peoples worldwide. Thereby, the Bloc identitaire, which one might accurately describe as one of the Nouvelle Droite's stepchildren, in many respects has sought to update the catechism of European racism as outlined by Comte Arthur de Gobineau, the author of On the Origins of the Inequality Among the Races (1851-54).

According to Gobineau, racial mixing leads to the "exhaustion" of Aryan stock, a process of depletion that culminates inexorably in a condition of generalized cultural stagnation. As Gobineau observes: "The mixing of blood is the generative motor [and] the destructive evil of all civilization" - a tendency that culminates in the "confusions" and "disorders" of "democratic egalitarianism." Consequently, "When the majority of citizens sense that mixed blood is coursing through their veins, they feel compelled to affirm that all men are equal, thereby elevating their own condition to a universal and absolute truth." 4

\footnotetext{
3 See, Timothy McCulloch, "The Nouvelle Droite in the 1980s and 1990s: Ideology and Entryism, the Relationship with the Front National," French Politics 4, (2006), 158-59: Whereas "in 1980, there were no nouvelle droitistes in the politburo of the $\mathrm{FN}$, by 1994, there were six, ... Bruno Mégret was delegate general in charge of party studies, propaganda, training, and communication, while Yvan Blot the was the personal adviser of Jean-Marie Le Pen ... Without this evolution in Nouvelle Droite influence, it is highly unlikely the FN would have incorporated concepts such as" National preference" into party policy."

4 Arthur de Gobineau, Essai sur l'inégalité des races humaines (1853-55), (Paris: Bibliothèque de la Pléiade, 1983), 344, 173. See also, Pierre-André Taguieff, La Couleur et la Sang: Doctrines Racistes à la française (Paris: Mille et Une Nuit, 1998), 36.
} 
I have treated the rather bizarre Dominique Venner episode at some length insofar as it illustrates my main thesis that under Marine Le Pen, "the FN of [today remains] a far-right party. It is not a new party. It is simply and logically the extension of its predecessor. Its history began in autumn 1972 and continues today" (Igounet).

Marine Le Pen's father, Jean-Marie, founded the National Front in 1972. Now 88, Jean-Marie began his political career in the 1950 s as a member of a short-lived, right-wing populist party founded by Pierre Poujade. Prior to entering politics, the elder Le Pen served as a foot soldier in French Indochina and then as a paratrooper during the Algerian war (1954-62). In the past, he has justified - even flaunted - the French army's use of torture against Algerian civilians.

During the 1960s, Le Pen founded a "record company" that specialized in the distribution of Nazi propaganda. Among its more memorable titles were "Voices and Songs of the German Revolution, 1933-39" and "Wehrmacht au combat, 1941-42." In 1965, for these infractions, and Le Pen was fined Fr.10,000 and given a two-month suspended prison sentence for "apologizing for war crimes."

The following remarks that Le Pen made during the late 1960 s offer useful insight into his political worldview at the time:

In an epic where atheism is growing by the day, young people need order and having disappeared in an apocalypse of fire, bombs, and blood, Hitler's soldiers have become martyrs ... searching for purity, even if it's a purity that is allied with evil (J. ALGAZY, 73). stability. Given the precipitous decline of 'morals' [moeurs], there is all the more need for a moral order to buttress them. Today, young people desire certitude... From this perspective, the SS, with its uniform, is like the priest with his cassock [soutane].
At the time, prominent among French far-right circles were several members of the Waffen SS Charlemagne Brigade (e.g., Francois Brignaud); but also, a number of former OAS militants, many of whom, like Dominique Venner, had been imprisoned for treason during the Algerian war. These ex-OAS fighters were consumed with a visceral hatred of President Charles de Gaulle for having betrayed the cause of French Algeria. On these grounds, they denounced the Fifth Republic as politically illegitimate, just as, during the 1930s, the various "leagues" and integral nationalists allied with Action Française had excoriated the Third Republic, embracing the watchword, "mieux Hitler que Blum" (better Hitler than Popular Front prime minister Léon Blum).

True to his political roots, over the years, the elder Le Pen gained notoriety as a result of a series of anti-Semitic assertions and outré pronouncements. He has gone on record saying that things weren't so bad for France during the Nazi occupation (1940-44). On more than one occasion, he has claimed that, in the course of World War II, the Holocaust was a mere "detail." In commenting on Jewish journalists or politicians, he has resorted to crude puns that allude to the Final Solution: "Durafour crématoire" to refer to thenMinister of Public Service Michel Durafour; for entertainer Patrick Bruel, Le Pen threatened to provide a "fournée" or "oven," since in French "brûler" means "to burn." Because various form of hate speech, including Holocaust denial, are criminal offenses in France, the elder Le Pen has been prosecuted and fined on at least 19 occasions.

The "Bruel-fournée" episode occurred in June 2014, just a few weeks following the National Front's stunning breakthrough in the European parliamentary elections. In other words, just as it appeared that Marine Le Pen's strategy of "normalization" had been successful, Jean-Marie's gaffe threatened to relegate it once again to the political fringe. Marine Le Pen's reaction was forceful and swift: She demonstratively instituted a party 
ban against her father. However, what seemed to trouble her was less the anti-Semitic tenor of the elder Le Pen's remarks than that he had made them publicly. Thus in commenting on her father's tasteless wordplay, Marine claimed that the problem lay chiefly with the "malevolent interpretation" to which they had been subjected by the French journalists, rather than his comments per se.

Historically, the elder Le Pen's publicity-mongering tactics were inordinately successful in garnering attention for the National Front cause. His efforts to position the FN as a credible alternative to France's main center-right and center-left parties, the RPR (Rassemblement pour la République; now, the Republicans) and the Socialists, crested in 2002 when, in an event that the French still regard as the political shock of a lifetime, the National Front succeeded in edging out Socialist Party candidate Lionel Jospin in the first round of that year's presidential elections [2017].

However, two weeks later, the National Front was soundly defeated in the second round. It soon became clear that, under Jean-Marie's leadership, the party had reached its zenith of popular support. Moreover, in the 2007 presidential elections, the party faltered badly: Its share of the electorate dwindled to 10 percent - a 7 percent diminution in comparison with its 2002 results - and it tumbled to fourth place among French political parties.

From the moment she inherited her father's mantle as party leader, in 2011, Marine Le Pen's main goal has been to endow the National Front with a veneer of political respectability in order to significantly expand the party's electoral base - an objective that had proved next to impossible under Jean-Marie's erratic stewardship. In this respect, she has been wildly successful, and the $\mathrm{Na}$ tional Front's political fortunes have escalated correspondingly. Estimates suggest that under her leadership party membership has doubled, from 40,000 to 80,000 members.

One of the core elements of Marine Le Pen's "normalization" (dédiabolisation) strategy - and one that, taken by itself, constitu- tes an impressive bit of lexical sleight-of-hand - has consisted in the adoption of orthodox French Republican rhetoric. Thereby, she has sought to mask the party's "national revolutionary" origins among neofascists and OAS types in order to reassure French voters of the FN's constitutional bona fides and political legitimacy.

In this respect, one of Marine Le Pen's key terminological innovations has been her embrace of what the French call "laicité" or secularism. Although, prima facie, such usage may not seem controversial, it is also fraught insofar as it risks offending so-called "integrists" among the FN's more traditional "Catholic wing." For this reason, the recent controversy over gay marriage - la manif pour tous - has threatened to jeopardize Marine Le Pen's "modernization" strategy. And on these grounds, she has disdained the headline-grabbing anti-gay marriage movement, so dear to French conservatives, declining to endorse it and shunning its sizeable rallies.

By the same token, Marine Le Pen's advocacy of "laïcité" has yielded a number of distinct, concrete political advantages. Prominent among those advantages is that the appeal to laïcité allows Le Pen a respectable, constitutional basis to rail against the dangers of Islam without mentioning the word and in stark contrast with Le Pen senior - without appearing racist. In this respect, as the recent, high-profile controversies over the Islamic head scarf (Foulard) and the "burkini" show, her views appear to be no different than arch-republicans among the Socialists and the conservatives, who also censure public expressions of religious loyalty - unless, of course, those expressions happen to assume the form of a cross.

A watershed moment in the National Front's political fortunes arrived with the May 2014 elections to the European Parliament. The National Front readily outshone the competition - Hollande's Socialists and Nicolas Sarkozy's UMP (Union pour un mouvement populaire). With 25 percent of the vote, it succeeded in becoming France's leading political 
vote getter. Then, in December 2015, capitalizing on the rising tide of Islamophobia that followed the devastating November 13 Paris terror attacks, the National Front's share of the electorate soared to 28 percent in the first round of regional elections - although National Front candidates were denied the major political breakthrough that many political experts had forecast.

Nevertheless, in the lead-up to next year's presidential elections, and with France's mainstream political parties in a state of considerable disarray - at 12 percent, President François Hollande's approval rating is the lowest of any postwar French head of state - there are few grounds to dispute the, disturbing prognosis that France's political future belongs to the National Front.

Hence, the question of the hour seems to be: Once one penetrates the thick rhetorical smokescreen, are there genuine differences of substance between the two Le Pens, père and fille? Here, the answer seems to be a resounding "no."

The strategy of meretriciously invoking the precepts of political liberalism to mask an ethnocentric and xenophobic agenda was pioneered by the Nouvelle Droite (New Right) during the 1980s. This approach was conceived and popularized by an influential group of right-wing publicists associated with two well-funded, far-right think tanks: the Club de L'Horloge and GRECE. Alluding to the Italian Marxist philosopher Antonio Gramsci's notion of hegemony, the Nouvelle Droite's intention was to facilitate a so-called "Gramscism of the Right." Its objective was to counter the post-1968 predominance of left-wing political ideas by furtively introducing a discursively palatable version of neofascist ideology. The operative assumption was that ideational domination was a necessary prelude to the attainment of political power. As Jean-Marie Le Pen explained, revealingly, in his book, Les Français d'abord: "Semantics are not neutral. One utilizes them like weapons in a combat where, at times, words kill more assuredly than bullets."
Since, in the aftermath of World War II, old-style European racism had been largely discredited, in order to rehabilitate neofascist political goals a novel approach was needed. The new strategy consisted in appropriating the language of "tolerance" and "self-determination" commonly associated with liberal democracy for the sake of establishing an authoritarian, ethnically homogeneous polity. Commentators have denominated the Nouvelle Droite approach "differentialist racism," since foremost among the "rights" it misleadingly invokes in order to expose the "hypocrisy" of liberal claims to tolerance is the "right to difference."

According to the paradigm of differentialist racism it is the representatives of France's republican status quo who foment intolerance, insofar as, by encouraging multiculturalism and racial mixing (métissage), they stifle the self-determination of peoples along ethnic lines. As Le Pen senior, relying on the "clash of civilizations" paradigm, never tired of pointing out, "multicultural societies are multi-conflictual societies." Thus in the National Front's political lexicon, "multiculturalism" has become a euphemism for "miscegenation," and the "right to difference" a coded expression for the non-acceptance of and refusal to tolerate North African immigrants and other minorities. The National Front contends that, although representatives of the democratic status quo purport to defend basic rights such as freedom of speech and freedom of assembly, such claims are hypocritical, insofar as the National Front and its followers are forbidden from employing these freedoms for their desired political ends: the promulgation of legislation that would penalize and vilify vulnerable immigrants.

Since, by now, many of these immigrants have become French citizens, the National Front program raises the specter of the revocation of French citizenship in specific cases - a practice that has not occurred in France since the Vichy regime. A content-analysis of Marine Le Pen's speeches reveals that she consistently distinguishes between "French citizens 
who were born in France of at least one French parent" and everyone else. In essence, Le Pen has effectively reconceived the definition of citizenship in order to distinguish between first - and second-class citizens - thereby raising the Orwellian prospect that, in certain cases, immigrants would be subject to having their citizenship retroactively annulled.

In her speeches, Marine Le Pen frequently seeks to turn the tables on mainstream defenders of civic and political equality. She portrays the National Front and its followers as victims and martyrs, alleging that the political establishment unfairly champions the civil liberties of immigrants, while suppressing those of Frontists. (The party name itself is reminiscent of anti-republican groups that, during the 1930s, actively - and, at times, violently - contested the Third Republic's legitimacy.) In a parallel vein, she contends that, whereas the National Front seeks to represent the interest of common men and women -the denizens of la France profonde, who Le Pen and her allies allege are the forgotten victims of globalization - at nearly every turn, self-interested bureaucrats in Brussels, the seat of the European Commission, seek to frustrate their efforts. Recourse to a language of "plots" and "conspiracies" - purported "enemies of the people" who are threatening the nation from all sides - is a recurrent leitmotif in the rhetorical arsenal of fascist demagogues.

Among a majority of French Catholics, who have recently been active in the massive protests against gay marriage known as "La Manif pour Tous" ("Demonstrations for All”), these images of persecution, which overlap with the history of Christian martyrdom - in particular, the Joan of Arc mythologem that Jean-Marie Le Pen was especially fond of invoking - have been well received. But they also play on the more general fears of Christian Europe's "inundation" by hordes of Muslim non-believers. The National Front's adeptness at the art of racial coding also emerges in the contrasts its leaders are fond of drawing between a previous generation of "successful" (read "white”) European immigrants and a more recent crop of purportedly "unassimilable," African migrants. The implicit assumption is that, whereas ethnically similar immigrants will blend in over time, non-European immigrants - whose very presence, in many cases, is a painful reminder of the legacy of French colonialism - will not. As Marine Le Pen, speaking of non-European immigrants, indelicately put it, "their attitudes and ways of being in society... are in total contradiction with the makeup of the French soul [sic]."

When all is said and done, the National Front's pseudo-libertarian appeals to political pluralism and the right to ethnic self-determination are little more than a swindle. They conceal a desire to return to the program of "integral nationalism" that, during the early decades of the 2oth century, was pioneered by anti-Dreyfusards such as Maurice Barrès and Charles Maurras. Both Barrès and Maurras held the egalitarian ideals of French Republicanism in contempt and sought to supplant them with the values of an ethnically homogeneous, authoritarian society. As Barrès declared in Scènes et doctrines du nationalism, "I enter into revolt against laws that are not the laws of my race." "Nationalism means resolving all questions on the basis of French interests." In opposition to the Dreyfusards, Barrès asserted that universal claims to justice or truth were chimerical. Instead, there were only a series of differential national truths.

Both then and now, integral nationalism's objective has been to replace the values of civic nationalism - the "ideas of 1789" - with the chauvinistic and prejudice-laden conception of ethnic nationalism. The ultimate goal is to redefine citizenship in accordance with the precepts of ethnic belonging (jus sanguinis), as opposed to equality before the law (jus soli).

In a New York Times op-ed last June congratulating the British on the Brexit result and urging other European nations to follow suit, Marine Le Pen openly betrayed her indebtedness to the political lineage of integral nationalism by alleging that only the existence of a "homogeneous European people" could 
provide a legitimate basis for the European Union. In the very next breath, she gainsaid the idea that "a Polish member of the European Parliament has the legitimacy to make law for the Spanish." But why shouldn't this be the case insofar as Poles and Spaniards belong to a common, supranational legal and political order, viz., the EU? [legislation is not race dependent but dependent on "principle" - modern natural law.]

What Le Pen is in essence proposing is that the right to legislate does not derive from one's legal status but, instead, is a function of ethnicity. Thus according to the stipulations of "Le Pen family values" - which, in a worrisome trend, are increasingly gaining currency throughout the continent - only ethnic Poles have the right to legislate in Poland, ethnic Spaniards in Spain, Français de souche or "ethnic French" in France, and so forth.

One can only begin to imagine the political chaos that would ensue from the attempt to enact the National Front's program of " differentialist racism" on a European scale. Moreover, generally speaking, claims to ethnic or national homogeneity are a political ruse or fiction contrived by political charlatans in order to further their own, persecutory ideological ends.

Once one ignites the political fuse of ethnopopulism, thereby placing various ethnic and national groups in competition with one another, there is no logical stopping point. France alone is comprised of Bretons, Normans, Alsatians, Basques, and Corsicans. How might one decide among these various groups which is genuinely "French," or which among them should be entitled to secede in accordance with the "right to national self-determination" that is disingenuously vaunted by the Le Pens?

After all, the contemporary inhabitants of these regions are the product of centuries of migrations and cross-cultural contact. On this basis alone, it is indisputable that, when questions of political right or legitimacy arise, to invoke ethnicity as a criterion is a phantasm - an ideological contrivance that political eli- tes employ to incite a frenzy of xenophobia among their credulous supporters.

During the 1930s, the program of integral nationalism came to fruition in the massive street protests orchestrated by far-right parties against so-called métis (non-white immigrants). It culminated in the proto-fascist, anti-republican rallying cry, "Better Hitler than [Popular Front leader] Léon Blum," who was both a Socialist and a Jew. Under Marshal Pétain's collaborationist Vichy government a regime that Le Pen senior openly views with nostalgia - immigrants were stripped of their civil and political rights, and new laws were passed privileging Français de souche or ethnic French. In fall 1940, French Jews - many of whom had resided in France for centuries - were de-emancipated: deprived of civil and political liberties and proscribed from a variety of influential professions (law, journalism, publishing, etc.). In retrospect, these measures were a statutory prelude to the Vichy authorities' deportation of some 75,000 Jews to Nazi death camps.

In contemporary Europe, the National Front's attempt to reintroduce ethnicity as the defining criterion of politics - "Les Français d'Abord!" ("Those who are French come first!") is a popular National Front slogan - is hardly unique. Its approach is shared by the vast majority of Europe's far-right, authoritarian populist parties. In a disturbing trend, European nations that had previously been more or less free of far-right political influence have recently succumbed.

Recently, the identitarian movement has made strides in Germany, especially among the Neue Rechte (the German translation of the French "Nouvelle Droite") brain trust animating far-right parties such as the Austrian Freedom Party (FPÖ) and the Alternative für Deutschland. 5

For the relevant background, see Jean-Paul Gautier, Lex Extrêmes droites en France: de la traversée du désert à l'ascension du Front National: 1945-2008 (Paris: Editions Syllepse, 2009), especially, chapter 10, "L'Impasse du Troisième voie et la naissance du Bloc identitaire," 301332. On the German New Right, see Sebastian Maass, Die Geschichte der Neuen Rechten in der Bundesrepublik Deutschland (Kiel: Regin Verlag, 2014). 
In the German regional elections last March, the far-right Alternative for Germany (AfD) party made significant inroads and is currently represented in eight of the 16 state legislatures. In the eastern state of Saxony-Anhalt, the AfD's share of the electorate rose to an alarming 24 percent. Apparently, AfD leader Frauke Petry's recent suggestion that, in the future, German border guards should use firearms to keep out unwanted asylum-seekers and prospective immigrants failed to deter voters, despite the fact that, in the eyes of many Germans, it touched a raw nerve in Germany's political history.

Earlier this month, in a stunning political development, the AfD outpolled Chancellor Angela Merkel's CDU in her home state of Mecklenburg-Vorpommern.

In many respects, the situation in Germany is a microcosm of a more general political trend. Across the continent, the mainstream center-left and center-right parties find themselves in the throes of a profound crisis. Voters have increasingly lost confidence in their pledges to remedy the precipitous rise in socioeconomic inequality that ensued in the wake of the 2008 financial crisis. Nor did the European Union's arrogant and heartless mishandling of last year's Greek debt crisis enhance voter confidence in its efficacy and sincerity.

Currently, with youth unemployment hovering around 50 percent mark in some of Europe's southern tier (notably Greece and Spain), the millennial generation's dreams of prosperity have been dashed. And thus, radical political alternatives are being sought, regardless of the costs or risks. In Greece and Spain, this mood has benefited left-wing parties like Syriza and Podemos. In Northern Europe, conversely, it has enhanced the standing of a panoply of far-right parties that have openly encouraged a return to the integral nationalist agenda of the 1930s: the misleadingly named "Freedom Parties" in Austria and the Netherlands; and in Scandinavia, the Danish People's Party and the Sweden Democrats.

Jean-Marie Le Pen once offered a me- morable illustration of the differentialist racism credo when he avowed, "I love North Africans, but their place is in the Maghreb, not in Metropolitan France." On another occasion, Le Pen sketched his infamous "concentric circle" approach to politics: "I like my daughters better than my cousins, my cousins better than my neighbors, my neighbors better than strangers, and strangers better than foes." In other words: not equality before the law, but blood and ethnicity are the defining criteria of politics. Four years ago, when Le Pen's granddaughter, the 25 year-old Marion Maréchal-Le Pen was elected as the youngest deputy ever to the French National Assembly, the incorrigible Jean-Marie Le Pen remarked: "c'est une bonne race!"

As things now stand, France is home to some 4-to-5 million Muslim immigrants. One can only begin to imagine the types of discriminatory legislation - not to mention the scale of the deportations - that would likely ensue should the National Front accede to power. During the 1990s, Interior Minister Charles Pasqua, then a member of Prime Minister Jacques Chirac's cabinet, sadistically fantasized about "charter flights for immigrants, from which one does not return." The Pasqua episode illustrates the capacity of far-right parties to determine the national political agenda even prior to their accession to political power.

When all is said and done, how concerned should we be about the FN's seemingly implacable rise under Marine Le Pen in view of France's impending presidential elections, which are slated for spring 2017? Here, it's important to keep things in perspective. Heretofore, France's two-round, majoritarian voting system has proven a highly effective mechanism of blocking the FN's aspirations to be a governing party - or, as Marine Le Pen has stated, to effect the transition from a party of "trailblazers" to one of "institution builders" ("Au temps des éveilleurs doit succéder celui des bâtisseurs"). Thus despite receiving relatively high scores in the first round (in the past, partly as a protest vote against the 
ineptitude of France's mainstream parties), they have been effectively "blocked" on the second round - as occurred, for example, in last December's regional elections.

The upshot of this state of affairs, which should not be lost sight of, is that at present the FN's level of political representation is modest. Currently, the FN is able to claim merely two representatives to the National
Assembly, three deputies to the European Parliament, 1500 members of city councils, eleven mayors, and 110 seats on regional councils - in sum, a veritable pittance in comparison with France's overall total of 562,000 elected officials.

Submetido em: 25-9-2017

Aceito em: 5-10-2017 